\title{
CIVIL SZERVEZETEK ÉS A CIVIL ELIT SZEREPE A TÁRSADALMI FOLYAMATOKBAN
}

\author{
(The Role of the Civil Organisations and the Civil Elite \\ in the Social Processes)
}

\section{REISINGER ADRIENN}

\section{Kulcsszavak:}

civil/nonprofit szervezet részuételi demokrácia aktív demokrácia állampolgári részuétel társadalmi részuétel civil elit

A tanulmány célja, hogy rövid áttekintést adjon a civillnonprofit szervezetek egyik legfontosabb társadalmi szerepéröl, a részvételi (aktív) demokráciában való részvételük formáiról és módszereiröl. Továbbá ismerteti azokat a feltételeket, amelyek ahhoz szükségesek, hogy ezeket a szerepeket hatékonyan tudják a gyakorlatban a szervezetek megvalósitani. Végül kitér arra, hogy ezekben a folyamatokban a civil elitnek milyen szerepe van.

\section{Bevezetö}

A civil/nonprofit szervezetek gazdaságban, társadalomban betöltött szerepéról könyvtárnyi szakirodalom áll rendelkezésre, azonban az, hogy a szervezeteknek milyen fontos szerepe van a részvételi (aktív) demokrácia kibontakozásában, csak az utóbbi években kerül egyre gyakrabban a szektort érintő tanulmányok középpontjába. A szektor ezen funkciója egyre meghatározóbbá vált/válik az elmúlt években a demokrácia építésében, így mára kijelenthető, hogy egy demokratikus berendezkedésủ országban a társadalmi szereplök hatékony együttmüködésének alapját a civil/nonprofit szervezetek képezik.

A tanulmány elsödleges célja, hogy - a szektor egy meghatározó társadalmi funkciójaként - bemutassa a civil/nonprofit szervezetek részvételi (aktív) demokráciában betöltött szerepét, ennek feltételeit. Kitérünk arra is, hogy mely szervezetek lehetnek azok, amelyek tevékenységük és szektorban betöltött szerepük által képesek lehetnek arra, hogy más szerveződések számára utat mutassanak a részvételi (aktív) demokrácia kibontakozásának folyamatában. A civil/nonprofit szervezetek szerepének bemutatása elött röviden ismertetjük, hogy mit értünk civil/nonprofit szervezeten, részvételi (aktív) demokrácián és társadalmi részvételen. 


\section{Fogalmi meghatározások}

\section{Civil/nonprofit szervezetek}

A civil társadalom meghatározására többféle megközelítés született az elmúlt évszázadokban, évtizedekben, alapvetóen minden fogalmi meghatározásban közös, hogy olyan társadalmi szerveződésekről van szó, amelyeket az államapolgárok önként, az államtól függetlenül hoznak létre érdekeik érvényesítése érdekében (Bartal 1999; Böhm 2002; Anheier 2005). A civil társadalom fenti fogalmi megközelítésével még ma is sokan azonosítják a nonprofit szektort, ami azonban ebben a formában nem állja meg a helyét, ugyanis a civil társadalmon belül a nonprofit szektor csak azokat a formalizált, intézményesült szervezeteket foglalja magában, amelyeknek hivatalos, jogilag definiált státusza van (Kuti 1998; Bartal 2005). Ebből következik, hogy a nonprofit szektor bizonyos értelemben szükebb kategória, mert nem foglalja magában a civil társadalom egészét, de egyben tágabb kategória is, mert a nonprofit szervezetek között találhatóak olyan szervezetek is, amelyeket nem egyéni kezdeményezés, hanem állami vagy önkormányzati akarat hoz létre. Ilyen szervezetek ma Magyarországon a közalapítványok, köztestületek és közhasznú társaságok, mely utóbbiak 2007. július 1-eje óta nem alapíthatóak, illetve 2009. június 30-áig át kellett alakulniuk nonprofit gazdasági társasággá, vagy meg kellett szünniük. Ezen szervezetek elsősorban alapítóik miatt nem tartoznak sem a civil társadalom, sem - ahogy a későbbiekben látni fogjuk - a nonprofit szektor fogalmi kategóriájába. Ennek ellenére a magyar jog a nonprofit szervezetek közé sorolja ezeket a szervezeteket. Több szakirodalom a fentiek miatt kvázi nonprofit szervezetekként említi őket és a magyar nonprofit szektor dualitásáról beszél (Bartal 1999; Harsányi 1999; Nárai 2008).

Hazánkban az 1990-es évek első felétől vált általánossá a civil szektor elnevezésére a nonprofit kifejezés. A nonprofit elnevezés a szektor legfőbb jellegzetességét ragadja meg: az ide tartozó szervezetek nem profitorientáltak, ezért nem tartoznak a piaci szektorhoz. Ez nem jelenti azt, hogy ezen szervezetek nem végezhetnek olyan vállalkozási és egyéb tevékenységet, amelyből nyereségük származna, azonban ezt a nyereséget nem oszthatják fel, csak céljaik megvalósítása érdekében használhatják fel (Kuti 1998).

Ezen a kritériumon kívül további öt olyan megkülönböztető eleme van a nonprofit szervezeteknek, amely elválasztja a piaci, az állami, illetve az informális szférától őket. Ez a felosztás tulajdonképpen Anheier és Salamon (1995) operacionálisstrukturális definíciójának felel meg. Ez a meghatározás az 1990-es években a John Hopkins University által folytatott nemzetközi összehasonlító kutatások eredményeként jött létre. A definíció egy fogalmi készlet, amely a szektor főbb jellemzőit tartalmazza, melyek a következők:

- Müködési autonómia és szervezeti elkülönülés a kormányzati szektortól, azaz a nonprofit szervezetek magán és nem állami kezdeményezésre jönnek létre. Mindez nem zárja ki, hogy a szektort az állam pénzügyileg vagy egyéb más módon támogassa. 
- Intézményesültség, önálló jogi személy: ez azt jelenti, hogy a szervezeteket hivatalos nyilvántartásba kell venni, a szervezeteknek vezetésüik, múködési szabályzatuk van, illetve a folyamatos múködés jellemzỏ rájuk.

- Minden nonprofit szervezetnek rendelkeznie kell az önkéntesség minimális szintjével, ami vonatkozik a tevékenységre és az adományokra is.

- Közhasznúság: a szervezetek tevékenysége a társadalmi közösség érdekeit szolgálja.

- Nem végezhetnek pártpolitikai tevékenységet, nem vehetnek részt kampányokban, illetve ideológiai meghatározottságuk miatt nem tartoznak a nonprofit szektorba az egyházak sem (de az azokhoz kapcsolódó vallásilag elkötelezett szervezetek igen).

Mivel a civil és a nonprofit szektor elhatárolása nem egyszerú, így tanulmányunkban a civil/nonprofit kifejezést használjuk. Civil/nonprofit szervezetek alatt értünk minden olyan szerveződési formát, amelyet részben vagy egészben állampolgári akarat hozott létre önkéntesen egyéni-, közösségi- vagy közcélok megvalósítása érdekében.

\section{A részvételi (aktív) demokrácia és a társadalmi részvétel}

A világ demokratikus berendezkedésủ államainak müködési alapja a képviseleti demokrácia rendszere, melynek értelmében az állampolgárok adott időszakonként választások formájában képviselőt választanak maguknak, rájuk bízva, hogy felelösen döntsenek az országot, adott területi egységet érintő kérdésekben (Sartori 1999). A képviseleti demokrácia egyik fontos jellemzője, hogy az állampolgárok számára csak behatárolt és korlátozott mértékủ politikai beleszólásnak enged teret (Kulcsár 1997), ezért is illetik a közvetett jelzővel. A képviseleti demokrácia rendszere a 20. század második felében került abba a helyzetbe, hogy nem minden esetben volt képes az érdekeket, különösen a helyieket megfelelöen érvényesíteni (Nizák-Péterfi 2005; Ugrin-Varga 2007). Megjelent az állampolgárok részéröl az az igény, hogy ők is szeretnének közvetlenül beleszólni saját környezetük fejlődésébe, nem csak a választások és egyéb népszavazások alkalmával, hanem a köztes időszakokban is.

A részvételi demokrácia működése azon az elven alapul, hogy az állami szereplök mellett a társadalom és a gazdaság szereplői is részt vesznek a környezetüket alakító folyamatokban, teszik ezt önként és teljes jogú félként (Sartori 1999). Danesh Chekki (1979) a részvételi demokráciát az emberek uralmaként értelmezi, olyan értelemben, hogy az állampolgárok olyan tetteket hajtanak végre, melyekkel szándékosan képesek befolyásolni a hatalmon lévők döntéseit, vagyis a közösség hatalommal való felruházásáról beszélhetünk.

Egyetértve több szerzővel (Kulcsár 1997; Sartori 1999; Nizák-Péterfi 2005; Ugrin-Varga 2007) a jövő demokrácia formája a képviseleti és a részvételi demokrácia között található. Ezalatt azt értve, hogy a képviseleti rendszer megtartása 
elengedhetetlen, viszont szükség van ennek kiterjesztésére, illetve szélesebb körben történő alkalmazására a részvételi elv alapján úgy, hogy teret kapnak az állampolgárok (közvetlenül és civil/nonprofit szervezeteken keresztül is) a döntések elökészítésében és a megvalósításban is, de a döntés joga továbbra is a képviselök kizárólagos joga marad. Nizák Péter és Péterfi Ferenc (2005) megfogalmazásában ez a képviseleti demokrácia kibővítését jelenti részvételi elemekkel. A cél az, hogy minél több szereplö, minél több kérdésben fejtse ki a véleményét, járuljon hozzá a döntések meghozatalához és vegyen részt a megvalósításban.

Továbbá, a fentiek értelmében a gyakorlatban a képviseleti demokrácia részvételi elemekkel történö megvalósítására használható lenne az aktív demokrácia kifejezés, amely olyan demokráciaformát jelöl, amelyben az állampolgárok aktívan részt vesznek az öket érintö folyamatokban együttmúködve az általuk választott képviselőkkel és egyéb helyi szereplökkel.

Mind a magyar, mind a külföldi szakirodalmakban találkozhatunk az állampolgári részvétel kifejezéssel, melynek tartalmi háttere sok esetben nem egyértelmủ, hiszen sokszor használják ezt a fogalmat a civil/nonprofit szervezetek részvételére is. $\mathrm{Az}$ állampolgári részvétel helyett célszerünek tartjuk a társadalmi részvétel kifejezést használni. Véleményünk szerint ez a kifejezés jobban érzékelteti, hogy nem csak az állampolgárok, hanem a civil/nonprofit szervezetek részvételéről is szó van.

\section{A civil/nonprofit szervezetek társadalmi részvétele}

\section{A részvétel formái}

Arnstein 1969-ben alkotta meg a közösségi részvétel létráját, melyben 8 fázisban különíti el a részvétel mélységét a teljes passzivitástól az aktív jelenlétig. A létra alsó két szintje fejezi ki a helyi szereplők teljes passzivitását, majd a következő három szint jelenti a részleges részvételt. Ennek tartalmi elemei között az informálás és a felmerült problémák kooperatív megoldása található. Arnstein a társadalmi részvétel legitimációjaként értelmezi az informálás szerepét, hiszen információk biztosítása nélkül nem lehet részt venni semmiben, így a helyi és központi állam egyik nagyon fontos szerepe, hogy információkhoz jutassa a lakosságot és a többi helyi szereplőt. A közeledés szerepét úgy értelmezte Arnstein, hogy bár a szereplöknek nincsen döntési joguk, de véleményezhetik a döntések elökészítése során az előzetes információkat. A partnerség már ennél magasabb fokú együttmüködést jelent, azonban igazán a 8. létrafok fejezi ki az állampolgárok „uralmát”, ahol egyik szereplönek sincs abszolút kontrollja, minden helyi szereplö ugyanolyan jogokkal és kötelezettségekkel rendelkezik. A szerző elgondolásában egy társadalomban mindhárom szint megvalósulhat, azonban több szerzővel egyetértve (Kulcsár 1997; Sartori 1999; Nizák-Péterfi 2005; Ugrin-Varga 2007) az állampolgárok és civil/nonprofit szervezetek döntésekben való részvétele gyakorlati megvalósításának nincsenek meg a feltételei. 
Chanan (1997) a részvétel két formáját részben más megközelítésböl mutatja be. $\mathrm{Az}$ egyik forma szerint a társadalom szereplöi aktív résztvevői a közügyeket meghatározó folyamatoknak, ebben az esetben a részvétel teljes körüként értelmezhető. A másik forma Chanan szerint a partnerség, mely intenzív együttmüködést jelent a közösségi szektor és a többi helyi szereplő között. Chananhoz hasonlóan több szerző (Burns-Hambleton-Hogget 1994; Gramberger 2001; Kweit M.-Kweit R. 2007) is azon a véleményen van, hogy a partnerség a társadalmi részvétel egyik még megvalósítható és magas hatékonyságot biztosító formája. A partnerségi kapcsolatok jelentőségét az adja (Gerston 2002), hogy gyakorlatilag minden társadalmi és gazdasági szereplö kapcsolatban van egymással a világban közvetlenuil vagy közvetve, minden szereplö az általa képviselt kapcsolatok révén egy-egy rendszer részét jelenti. A rendszerek jövője attól függ, hogy egymással a szereplök milyen formában és milyen mélységben képesek közös ügyek érdekében együttmüködni.

Egy másik részvételi megközelítés ötszintü modellben vázolja fel a részvételi lehetőségeket (Building new... 2006). Az 1. táblázat az öt szintet mutatja be az adott részvételi forma célja és a résztvevőknek tett ígéretek alapján.

\section{TÁBLÁZAT}

A társadalmi részvétel módjai

(Forms of the Social Participation)

\begin{tabular}{cc}
\hline Cél & Ígéret
\end{tabular}

\begin{tabular}{ll}
\hline 1. Informálás & $\begin{array}{l}\text { Állampolgárok, szereplök infor- } \\
\text { mációval történö ellátása. }\end{array}$ \\
& $\begin{array}{l}\text { Elérni, hogy a kiadott informáci- } \\
\text { 2. Konzultáció } \\
\text { sek is történjenek. }\end{array}$
\end{tabular}

3. Bevonás

\section{Együttmüködés}

5. Felhatalmazás
A fejlesztések során közvetlenül az érintett szereplökkel dolgozni.

A teljes fejlesztési folyamatban partneri együttmúködés (alternatívák kidolgozása, alternatívák közül megvalósítható kiválasztása).

A végsö döntés is az érintett szereplők kezében van.
Információk biztosítása.

A visszajelzések döntésre gyakorolt hatásáról informálják a szereplöket.

A vélemények megjelennek az alternatívában, és történik viszszajelzés róluk.

A vélemények lehetö legmagasabb szintú figyelembe vétele.

Teljes mértékben a szereplök véleménye, döntése a mérvadó.

Megjegyzés: A modell kidolgozása az IAP 2 (International Association for Public Participation) szervezet nevéhez füződik.

Forrás: Building new... (2006). 
A 2. táblázat a fentiekben tárgyalt részvételi formák alapján mutatja be a civil/ nonprofit szervezetek lehetséges szerepeit az egyes területi szinteken. A szerepek felsorolása részben szakirodalmi, részben saját gondolatokon alapul, a területi szintek megjelölése szintén saját véleményt tükröz.

\section{TÁBLÁZAT}

Civil/nonprofit szervezetek szerepe az aktív demokráciában helyi, területi és nemzeti szinten

(The Role of the Civil/Nonprofit Organisations in the Active Democracy at Local, Spatial and National Level)

\begin{tabular}{|c|c|c|c|}
\hline Szerepek & Helyi & Területi & Nemzeti \\
\hline A döntések minöségének javítása & $\mathrm{x}$ & $\mathbf{x}$ & $\mathrm{x}$ \\
\hline Legitimáció megteremtése & $\mathrm{x}$ & $\mathrm{x}$ & $\mathrm{x}$ \\
\hline Átláthatóság megteremtése & $\mathrm{x}$ & $\mathrm{x}$ & $\mathbf{x}$ \\
\hline A helyi szereplők közötti kapcsolatépítés & $\mathrm{x}$ & $\mathrm{x}$ & \\
\hline A helyi szereplők közötti kapcsolattartás & $\mathrm{x}$ & $\mathrm{x}$ & \\
\hline $\begin{array}{l}\text { Jövőképelemekkel stratégiák kidolgozásához való } \\
\text { hozzájárulás }\end{array}$ & $\mathrm{x}$ & $\mathrm{x}$ & $\mathrm{x}$ \\
\hline A stratégai tervezés biztonságának növelése & $\mathbf{x}$ & $\mathrm{x}$ & $\mathbf{x}$ \\
\hline Helyi lakosok közösségbe szervezése & $\mathbf{x}$ & & \\
\hline $\begin{array}{l}\text { Lehetőséget teremtenek emberek számára, hogy } \\
\text { fontosnak érezzék magukat }\end{array}$ & $\mathrm{x}$ & & \\
\hline $\begin{array}{l}\text { Érdekérvényesítés eszközeinek megtanítása szer- } \\
\text { vezeti keretek között állampolgároknak }\end{array}$ & $\mathrm{x}$ & $\mathrm{x}$ & \\
\hline Bizalom építése & $\mathrm{x}$ & $\mathrm{x}$ & $\mathrm{x}$ \\
\hline $\begin{array}{l}\text { Megtanítani az embereknek, hogyan kell közösségi } \\
\text { szinten gondolkodni }\end{array}$ & $\mathrm{x}$ & $\mathrm{x}$ & \\
\hline Fejlesztési alternatívák közös kidolgozása & $\mathrm{x}$ & $\mathrm{x}$ & \\
\hline $\begin{array}{l}\text { Fejlesztési dokumentumokhoz helyi elképzelések, } \\
\text { vélemények összegyủjtése }\end{array}$ & $\mathbf{x}$ & $\mathrm{x}$ & \\
\hline $\begin{array}{l}\text { Fejlesztési dokumentumok kidolgozásában való } \\
\text { részvétel aktív szereplóként }\end{array}$ & $\mathrm{x}$ & $\mathrm{x}$ & \\
\hline $\begin{array}{l}\text { Felmérni, hogy a tervezett változtatások milyen } \\
\text { hatással lehetnek az érintettekre }\end{array}$ & $\mathrm{x}$ & $\mathrm{x}$ & \\
\hline A fejlesztési célok megvalósításában való részvétel & $\mathrm{x}$ & & \\
\hline A fejlesztési folyamatok értékelése & $\mathrm{x}$ & & \\
\hline $\begin{array}{l}\text { Állampolgárok és állami, önkormányzati szereplők } \\
\text { közötti kommunikációs csatorna }\end{array}$ & $\mathbf{x}$ & $\mathbf{x}$ & $\mathrm{x}$ \\
\hline
\end{tabular}

Forrás: Részben Fennell et al. (2008) (első öt szerep), illetve Rechnitzer (1998) (6.-7. szerep) alapján saját szerkesztés.

Az egyes részvételi formák megismerése után elmondható, hogy a társadalmi részvétel gyakorlati megjelenésében nem az a lényeg, hogy minden állampolgárt és minden szervezetet mindenbe be kell vonni, hanem az, hogy a meghatározó ügyekben és a fejlesztési kérdésekben legyen kommunikáció, hallgassák meg a szereplöket, és legyenek egyértelmü kapcsolatok, együttmüködési formák. 


\section{Részvételi módszerek}

A társadalmi részvétel eszközeit és technikáit a szakirodalom két nagy csoportba sorolja (Ploštajner-Mendeš 2005):

- Tradicionális/hagyományos technikák,

- Új/modern technikák.

A hagyományos technikák csoportjába alapvetően az eddigiekben is viszonylag széles körủen alkalmazott eszközök tartoznak, melyek elsősorban az önkormányzati mủködéshez kötődnek, illetve ide sorolják a hagyományos politikai részvételi módokat is, mint pl. a helyhatósági választásokat, a népszavazásokat. A hagyományos tecnhikák legismertebb formái a következők:

- Közmeghallgatás,

- Lakossági fórum,

- Közgyülésen való részvétel,

- Önkormányzati bizottságban való részvétel,

- Önkormányzat munkájában szakértőként való részvétel,

- Tiltakozások szervezése, azokon való részvétel.

A modern technikák alakalmazásának hátterében az áll, hogy a mai társadalmi, gazdasági komplexitás megkívánja, hogy az állampolgárok, civil/nonprofit szervezetek a fentieknél több lehetőséget kapjanak a részvétel során. Legyenek olyan közösségi terek, amelyek alkalmasak arra, hogy a helyi szereplők egymással szoros együttmüködésben valósítsanak meg fejlesztési célokat. Az ebbe a csoportba sorolható technikák az aktív demokrácia eszközeiként alkalmazhatók. Módszerei a következők:

- Fórumok,

- Konferenciák,

- Workshopok,

- Kerekasztal-beszélgetés,

- Kérdöívek, interjúk,

- Képzések,

- Kutatások,

- Véleményezés,

- Fejlesztési dokumentumok elkészítésében való részvétel,

- Civil Fórumok,

- Állampolgári Tanács,

- Jövőmühely. 


\section{A civil/nonprofit szervezetek társadalmi részvételének feltételei}

\section{A helyi szereplök pozitív attitüdje}

Kiemelten fontos szempont, hogy a társadalmi szereplök részvétele csak akkor lehet sikeres, ha két oldalról, vagyis fentről és lentröl egyszerre indul meg az ez irányú akarat. Ez azt jelenti, hogy a központi állami szereplők felismerik, hogy fejleszteni az érintett szintű szereplők bevonása nélkül nem lehet, másrészt felismerik, hogy az állampolgárok és civil/nonprofit szervezetek bevonása nem arról szól, hogy kész koncepciókkal állnak a döntéshozók az érintettek elé, hanem arról, hogy a közügyekben és a fejlesztésben már az elképzelések kidolgozása előtt aktívan számolnak a helyi szereplők jelenlétével. Másrészt az állampolgároknak is fel kell ismerni, hogy életük és környezetük hatékonyabb alakulásához nem csak egyéni szinten kell gondolkodni, hanem közösségi szinten is, és ki kell használniuk minden lehetőséget, hogy az őket érintő közügyekben, fejlesztési feladatokban véleménynyilvánítóként és megvalósítóként is részt vegyenek. E kétirányú felismerés nem történhet külön, hiszen, ha nincs állami akarat, akkor hiába vannak alulról jövő kezdeményezések, azok vagy egyáltalán nem, vagy csak nagy nehézségek árán jutnak célba, illetve, ha van állami akarat, de helyi szintủ nincs, akkor nehéz motiválttá tenni az embereket. Így az egymás felé közeledő feleknek közel egy időben kell elindulniuk egymás felé és az egymás felé tartó úton találkozni, majd egymást erösítve haladni tovább.

Alapvetöen az államnak nagy szerepe van abban, hogy ezek a folyamatok elinduljanak, hiszen a hatékony megvalósuláshoz szükség van a részvétel jogi kereteinek megalkotására és annak betartatására is. Szükség van olyan intézmények felállitására vagy meglévők átstrukturálására, amelyek az elejétől kezdve képesek a társadalmi részvételi technikák alkalmazását koordinálni. Az állampolgárok és civil/nonprofit szervezetek véleményének összegyüjtése megfelelő intézményi hátteret és megfelelő szaktudással rendelkező szakembereket kíván.

\section{Erös civil/nonprofit szektor, civil barát önkormányzatok}

A részvétel jelentőségének civil és állami/önkormányzati oldali felismerése mellett egy erős és müködőképes civil/nonprofit szektor jelenlétére is szükség van. A következő belső (szervezeten belüli) és külső (szervezeten kívüli) tényezőkkel jellemezhető az erős civil/nonprofit szektor:

- Belső tényezők: megfelelö bevételi szerkezet, hatékony irányítási, menedzser funkciók, megfelelö érdekérvényesítö-képesség, megfelelő foglalkoztatási (foglalkoztatottak, önkéntesek) szerkezet, széles körủ kapcsolatrendszer, együttmüködési-hálózatok, világos jövökép, rugalmasság (belső, külső környezetre történő reagálás), hatékony programok. 
- Külső tényezők: megfelelő jogszabályi háttér, megfelelő politikai környezet, civil barát önkormányzatok, társadalmi elfogadottság, gazdasági elfogadottság, társadalmi töke magas szintje.

Egy országban minél több szervezet jellemezhető a fenti tényezökkel, annál sikeresebb lehet a civil/nonprofit szektor müködése. Fontos kiemelni, hogy a szervezetek elsődlegesen saját müködésükért felelősek, míg a külső tényezők alapvetöen a többi társadalmi, gazdasági és állami, önkormányzati szereplő döntéseitöl függ. Így a sikeres civil/nonprofit szektor nemcsak a szervezetek tevékenységétől, hozzáállásától függ, hanem a többi szereplő által a szervezetek sikeressége irányába tett lépésektől is.

Bőhm Antal (1999) alapvetỏen az állampolgárok aktivitásának szerepére hívja fel a figyelmet a szektor müködésével kapcsolatban. Azokban az országokban alakulhat ki erős civil/nonprofit szektor, ahol az állampolgárok képesek az államtól független szervezeteiket létrehozni, és nagy arányban tagként vagy egyéb formában tevékenykedni bennük. Ahol az állampolgárok életére az egyéni stratégiák kialakítása és a privát szférába való visszavonulás a jellemző, ott kevésbé lehet hatékony a szektor müködése. A szerző szerint ez utóbbi jellemzi föként a volt szocialista országokat, ahol jelenleg is a szektor formálódásának lehetünk tanúi.

Az erős civil/nonprofit szektor egyik meghatározó külső tényezöje a civil barát önkormányzatok mủködése. Megállapítható, hogy a szervezetek mủködésének egyik fontos eleme, hogy olyan helyi társadalmi, gazdasági környezet vegye őket körül, melyben mủködésük biztosítása megoldott, és a szervezetek valóban céljaik elérése és nem a mindennapi megélhetés érdekében tevékenykedhetnek.

\section{Bizalom}

Az aktív demokrácia müködésének alapját képezi az állami, piaci és társadalmi szereplők bizalma egymás és az országban zajló folyamatok irányába. A bizalom annyit jelent, ha bízunk valakiben vagy valamiben, akkor cselekedeteink során nem kell állandóan azzal foglalkozni, hogy mi történik, ha a másik fél nem úgy cselekszik, ahogy azt megígérte. Így lehetővé válik, hogy a bizalommal teli gazdasági és társadalmi folyamatok során teljes mértékben az adott folyamatokra koncentráljunk, így hatékonyabb lesz a megvalósítás folyamata és a végeredmény is.

Fontos kérdésnek tartjuk annak vizsgálatát, hogy milyen szerepe lehet a civil/ nonprofit szervezeteknek a bizalom építésében? A civil szektor egy neves kutatója, Henry Hansmann (1991) 1980-ban alkotta meg Bizalomelméletét a szervezetek létjogosultságára vonatkozóan. A piacok normális működéséhez korrekt szerződéses kapcsolatok kellenek, ebben az esetben mindkét fél, eladó és vevő is pontos információkkal rendelkezik. Az elmélet szerint a legtöbb jószág esetében ez teljesül is. Viszont egészen más a helyzet a közjavak esetében, ahol gyakran megjelenik a potyautas probléma, vagyis azok is igénybe vehetnek bizonyos szolgáltatásokat, akik nem is fizettek érte, illetve a közjavaknál sok esetben nehéz eldöntetni, hogy tényleg azt kapja-e az ember a pénzéért, amit elvárhatna. Itt sokkal eröteljesebben 
jelentkezik az információhiány, ami a profitorientált szereplőket arra csábíthatja, hogy becsapják a vevőket. Ez a csábítás kisebb lehet azoknál a szervezeteknél, amelyek müködésük során nem a profitot, hanem a köz javának szolgálatát helyezik középpontba, vagyis a civil/nonprofit szervezeteknél. Sok esetben a bizalom építését is éppen az segíti elö, ha az emberek látják és tudják, hogy bizonyos szolgáltatások igénybevétele során nem a becsapás ténye érvényesül, hanem a korrekt tranzakciós folyamat. Természetesen a civil/nonprofit szervezetek önmagukban nem elegendőek ahhoz, hogy a bizalmat magas szintre lehessen visszaállítani, de példát mutathatnak, illetve ezáltal is erősíthetik a társadalmi összetartozás érzését, a társas kapcsolatok hatékonyságát.

\section{A civil elit szerepe a részvételi (aktív) demokráciában}

Mielőtt rátérnénk arra, hogy miért tartjuk fontosnak a civil elit szerepét az aktív demokráciában, röviden ismertetjük, hogy mit értünk civil elit alatt a tanulmányban.

Az elit fogalmát már számos szerző meghatározta, jelen tanulmány szempontjából Mills (1972) és Bourdieu (1986) megközelítését emelnénk ki. Mills azt hangsúlyozza, hogy az elit mindig döntéshozatali pozícióban van, míg Bourdieu-nél az elit csoportjába (a társadalom domináns csoportjai) azok tartoznak, akik a legtöbb tökefajta birtokában vannak társadalmi, gazdasági, kulturális és szociológiai értelemben is. Ezek alapján a civil elit értelmezésünkben a civil/nonprofit szektornak egy olyan részét képezi, amely a szektorban betöltött szerepébỏl adódóan képes vezető, irányt mutató, segítỏ és támogató szerepet betölteni elösegítve a többi szervezet hatékonyabb müködését. Cziboly Ádám (2008) a civil szféra elitjeként kétfajta szervezettípust említ meg: az ernyőszervezeteket, illetve azokat a szervezeteket, amelyek külföldi tőkéből jöttek létre és/vagy amelyek külföldi támogatásban részesülnek. Véleményünk szerint a civil/nonprofit szféra elitje ennél tágabb kört magában foglalhat, ennek feltétele, hogy a szervezetek maguk is képesek legyenek felismerni, hogy melyek azok a szervezetek a környezetükben, amelyek a fentiekben bemutatott szerepkörrel rendelkeznek.

Ezen szervezetek éppen a helyi folyamatok nagyobb mértékü ismeretének birtokában játszhatnak jelentős szerepet a társadalmi részvétel folyamatában. Az elözö fejezetben kiemelésre kerültek, hogy melyek azok a feltételek, amelyek szükségesek ahhoz, hogy az aktív demokrácia minél szélesebb körü eszközrendszere megvalósulhasson a gyakorlatban. Meglátásunk szerint éppen a szektor elitjének számító szervezetek lehetnek azok, amelyek képesek lehetnek utat mutatni a többi szervezetnek, alapozva tevékenységüket arra a tudástöbbletre, amellyel azáltal rendelkeznek, hogy pl. vezetöik olyan tulajdonságokat birtokolnak, amelyek képesek a szervezeteket elindítani az érdekérvényesítés útján. Úgy gondoljuk, hogy ezen szervezetek vezető szerepe gyakorlati megvalósulásának egyik sarokköve, hogy a szektor szervezetei hajlandóak legyenek elismerni létjogosultságukat és azt, hogy ezek a 
szervezetek lehetnek azok, amelyek segítésével hatékonyabbá tehetik kapcsolataikat, több információhoz juthatnak és biztosabbá tehetik gazdálkodásukat.

A társadalmi részvétel minél magasabb szintú megvalósításában így véleményünk szerint meghatározó szerep jut a civil elitnek. Ezen szervezetek pozíciójukból adódóan magasabb színvonalon tudják a saját és a szektor érdekeit képviselni. Ha ők birtokában vannak a részvétel alapvető ismereteinek, átadhatják ezt a tudást mind a helyi döntéshozók, mind az állampolgárok és a civil/nonprofit szektor felé.

\section{Összegzés}

Ahhoz, hogy a fenti folyamatok müködőképesek legyenek, a tanulmányban bemutatott feltételeknek teljesülniük kell, vagy legalábbis elöremozdulás szüikséges annak érdekében, hogy a változások elindulhassanak. Bỏhm (1987), Boda (2008) és Battistoni (2000) véleményét támasztjuk alá, mely szerint a helyi szereplőket mind a társadalmi, gazdasági, mind az önkormányzati oldalt - képessé kell tenni arra, hogy felismerjék, együtt van szuikség rájuk a hatékony részvételi folyamatok érdekében. Az aktív demokrácia egyik alapja, hogy a helyi és területi szereplők egymással intenzív kommunikációt tartsanak fenn, képesek legyenek egymással partnerségben együttmüködni. A képessé tevés azon szakemberek feladata lehet többek között, akik megfelelỏ eleméleti és gyakorlati tudás birtokában rendezvények, fórumok, oktatás keretei között át tudják adni az érintett szereplöknek az aktív részvételt megalapozó ismereteket. Ehhez természetesen az szükséges, hogy az emberek, szervezetek képviselői el is menjenek ezekre a találkozókra. A motiváció alapja lehet olyan kiadványok széles körü elterjesztése, amelyek a helyi fejlesztés gyakorlatának sikeres példáit mutatják be közérthető módon.

Úgy gondoljuk, hogy az emberek közötti bizalom visszaállítása jelentheti a részvételi aktivitás növekedésének bázisát. Ennek véleményünk szerint két útja van: egyrészt a történelmi sajátosságok miatt szuikség van arra, hogy az emberek a demokrácia tanulása során saját maguk által megtapasztalva jöjjenek rá arra idővel, hogy mit jelent megbízni a társadalmi, gazdasági szereplőkben. Másrészt szükséges lehet például civil/nonprofit szervezetek kezdeményezésével olyan találkozók szervezése, ahol a felek kötetlen beszélgetések során megismerhetik egymás gondolatait, továbbá tanulhatják saját tapasztalatok alapján az egymás közötti kommunikációt. Ennek egyik feltétele, hogy az emberek a mindennapi problémájukat háttérbe szorítva, vagy éppen ezen beszélgetések keretében elötérbe helyezve szükségét érezzék az egymással folytatott érdemi közösségi kommunikációnak.

Összességében úgy gondoljuk, hogy egy ország demokratikus mủködéséhez mind társadalmi, mind gazdasági értelemben szükség van arra, hogy a részvételi demokrácia megvalósításában minden érintett szereplö részt vegyen az állami, önkormányzati szereplők mellett. Így egyrészt hatékonyabb döntések születhetnek, másrészt az emberek közösségi integrációja is elősegíthető. 


\section{Irodalom}

Anheier, H.K.-Salamon, L.M. (1995) Szektor születik. Nonprofit Kutatócsoport, Budapest.

Anheier, H.K. (2005) Nonprofit Organizations. Routledge, London and New York.

Arnstein, Sh.R. (1969) A Ladder of Public Participation. - Journal of the American Institute of Planners. 4. 216-224. o.

Bartal A.M. (1999) Nonprofit alapismeretek kézikönyve. Ligatúra Kiadó, Budapest.

Bartal A.M. (2005) Nonprofit elméletek, modellek, trendek. Századvég Kiadó, Budapest.

Battistoni, R.M. (2000) Service Learning and Civic Education. - Mann, Sh.-Patrick, J.J. (eds.) Education for Civic Engagement in Democracy: Service Learning and Other Promissing Practices. Educational Resorces Information Center, Bloomington, USA. 29-44. o. www.eric.ed.gov Letöltve: 2009. március 6.

Boda Zs. (2008) A civil szervezetek a közösségi döntéshozatalban: participáció és kormányzás. - Bódi F. (szerk.) A területfejlesztés útjai az Európai Unióban. MTA Politikatudományi Intézet, Budapest. 159-168. o.

Bourdieu, P. (1986) The forms of capital. - Richardson, J. (ed.) Handbook of Theory and Research for the Sociology of Education. Greenwood, New York. 241-258. o.

Bőhm A. (1987) Helyi hatalom - lakossági részvétel. - Bőhm A.-Pál L. (szerk.) A helyi hatalom müködése. MSZMP KB Társadalomtudományi Intézete, Budapest. 11-35. o.

Bőhm A. (1999) Civil szervezetek a helyi társadalomban. - Comitatus. 3. 19-26. o.

Böhm A. (2002) Helyi társadalom, önkormányzatok, telepuilésfejlesztés. Agroinform Kiadóház, Budapest.

Building new communities. (2006) Outer Suburban/Interface Services and Development Committee, Melbourne. www.parliament.vic.gov/osisdc.au Letöltve: 2009. január 10.

Burns, D.-Hambleton, R.-Hogget, P. (1994) The Politics of Decentralisation: Revitalising Local Democracy. Macmillan, London.

Chanan, G. (1997) Active Citizenship and Community Involvement: Getting to the Roots. Discussion Paper. European Foundation for the Improvement of Living and Working Conditions, Dublin.

Chekki, D.A. (1979) Participatory Democracy in Action: International Profiles of Community Development. Vikas Publishing, Bombay.

Cziboly Á. (2008) Szubkulturák - A civil szektor kulturális szegmensének értékelése a Civil Éves Jelentésben. - Civil Szemle. 1-2. 105-118. o.

Fennell, E.-Gavelin, K.-Wilson, R. (2008) Better together: improving consultation with the third sector. Involve, Office of the Third Sector. www.involve.org.uk Letöltve: 2009. január 20.

Gerston, L.N. (2002) Public Plicymaking in a Democratic Society. M. E. Sharpe, New York, London.

Gramberger, M. (ed.) (2001) Citizens as Partners. OECD, France.

Harsányi L. (1999) A harmadik szektor. - Tóbiás P. (szerk.) Egyiuttmüködési lehetöségek civil szervezetek és a helyi önkormányzatok között. Demokratikus Jogokért Fejlesztési Alapítvány, Budapest. 9-23. o.

Hansmann, H. (1991) A nonprofit szervezetek közgazdasági elméletei. - Kuti É.-Marschall M. (szerk.) A harmadik szektor - Tanulmányok. Nonprofit Kutatócsoport, Budapest. 29-44. o.

Kulcsár K. (1997) Politikai rendszer és politikai kultúra. - Glatz F. (szerk.) A demokrácia intézményrendszere Magyarországon. Magyar Tudományos Akadémia, Budapest. 11-31. o.

Kuti É. (1998) Hívjuk talán nonprofitnak... Nonprofit Kutatócsoport, Budapest.

Kweit, M.G.-Kweit, R.W. (2007) Participation, Perception of Participation, and Citizen Support. American Politics Research. 3. 407-425. o.

Mills, C.W. (1972) Az uralkodói elit. Gondolat Könyvkiadó, Budapest.

Nárai M. (2008) A nonprofit szervezetek helye és szerepe a helyi társadalmak életében - A nyugatdunántúli nonprofit szektor helyzetfeltárása. Doktori disszertáció, ELTE Társadalomtudományi Kar, Szociológiai Doktori Iskola, Györ-Budapest.

Nizák P.-Péterfi F. (2005) A közösségi részvétel - társadalmi és hatalmi beágyazottság. - Márkus E. (szerk.) Ismerd, értsd, hogy cselekedhess. EMLA, Budapest.

Ploštajner, Z.-Mendeš, I. (2005) Citizens Participation. - How to Improve Development on Local Level? Fridrich Ebert Stiftung, Zagreb Office, Zagreb. 97-113. o.

Rechnitzer J. (1998) Terïleti stratégiák. Dialóg Campus, Budapest-Pécs.

Sartori, G. (1999) Demokrácia. Osiris Kiadó, Budapest.

Ugrin E.-Varga Cs. (2007) Új âllam-és demokráciaelmélet. Századvég Kiadó, Budapest. 


\title{
THE ROLE OF THE CIVIL ORGANISATIONS AND THE CIVIL ELITE IN THE SOCIAL PROCESSES
}

\begin{abstract}
ADRIENN REISINGER
There are lot of literature worlwide on the role of the civil/nonprofit organisations in the economy and the society, but only in the past few years got into the focus of these studies theimportance of the role of these organisations in the participatory (active) democracy. This function of the civil/nonprofit organisations are getting more and more important, nowadays it can be stated that this role is essential to an efficient democracy. The aim of my study is to give a short summary about one of the most important role of the civil/nonprofit organisations called the participatory (active) democracy. Further I present those requirementsw hich are necessary to be able to held on an efficient active democracy. Finally I show the role of civil elite in these processes.
\end{abstract}

